\title{
Phenotypic and marker-assisted characterization of new apple genotypes with high resistance to fire blight
}

\author{
Piotr Sobiczewski $(\mathbb{D})$ Sylwia Keller-Przybyłkowicz $(\mathbb{D})$ - Mariusz Lewandowski $(\mathbb{D} \cdot$ \\ Artur Mikiciński (D) Robert Maciorowski (i)
}

Accepted: 24 May 2021 / Published online: 31 May 2021

(C) The Author(s) 2021

\begin{abstract}
In the period 2016-2018 the susceptibility to fire blight of seven apple genotypes, including four recently bred was assessed. The studies showed that two of the genotypes (J-2003-05 and 'Early Szampion') are highly resistant to the disease. The indicator of assessment was evaluated by the size of necrotized part of terminal shoots after their inoculation with strain Ea659 of Erwinia amylovora. The analysis of disease incidence on individual shoots of both genotypes showed no symptoms on $92 \%$ and $100 \%$ of shoots inoculated in 2016, 83.8 and $77.0 \%$ of shoots in 2017 , and 87.8 and $77.3 \%$ of shoots inoculated in 2018 , respectively. Molecular tests based on 16 genetic markers revealed that genotype J-2003-05 possesses 10 resistance alleles (covering the region of interest from LG $3,5,7,10$ and 12). This genotype is derived from the cross between 'Melfree' and 'Sawa' and produces very large dark-red tasty fruits. Genotype 'Early Szampion' representing the selected hybrid from the cross of 'Gold Milenium' and 'Šampion', producing large, bright red, attractive fruits, was found to possess 10 resistance alleles (covering the region of interest from LG 3, 7, 10 and 12), Both genotypes have the prospect of being used in breeding programs and commercial planting.
\end{abstract}

Keywords Apple · Fire blight · Susceptibility ·

Phenotypic evaluation $\cdot$ Molecular markers

P. Sobiczewski $(\bowtie) \cdot$ S. Keller-Przybyłkowicz •

M. Lewandowski · A. Mikiciński · R. Maciorowski

The National Institute of Horticultural Research, ul. Konstytucji 3

Maja 1/3, 96-100 Skierniewice, Poland

e-mail: piotr.sobiczewski@ inhort.pl

\section{Introduction}

Fire blight caused by the necrotrophic bacterium Erwinia amylovora Burr. (Winslow et al.) (Sobiczewski et al., 2017) is one of the most important factors limiting apple production (Norelli et al., 2003; Peil et al., 2009; Vanneste, 2000). The bacterium is polyphagous infesting all aboveground organs across a range of over 130 host plant species, mainly belonging to the family Rosaceae (van der Zwet et al., 2012). As a result of infection, the attacked organs or whole plants often die quickly. The severity of disease basically depends on the presence and amount of the infection source, plant susceptibility and environmental conditions. The protection of apple trees against fire blight relies mainly on the integration of chemical treatments and cultural practices, but this does not guarantee full effectiveness in all conditions. Most limitations are associated with the survival of the pathogen on host plants, the variations in environmental factors, and the lack of efficient bactericides (Peil et al., 2009). The use of tolerant or highly resistant cultivars increases the possibility of reducing the harmfulness of the disease in orchard establishment (Kellerhals et al., 2011; Kellerhals et al., 2017; Norelli et al., 2003; Peil et al., 2009, 2020; Sobiczewski et al., 2015).

Currently, in the breeding programs of most countries the breeding of apple cultivars resistant to fire blight is not considered as a main priority. Nevertheless, it has been established that some of the scab-resistant cultivars (e.g. 'Florina', 'Liberty', 'MacFree', 'Novole') bred in recent decades show a high degree of resistance 
also to fire blight (Aldwinckle et al., 1999). However, these cultivars are not grown on a large commercial scale. Among the most resistant commercial apple cultivars are 'Starkrimson', 'Belle de Boskoop', 'Golden Spur' and Red Delicious (Lespinasse \& Aldwinckle, 2000; van der Zwet et al., 2012).

Within the German breeding program, aimed mainly at obtaining scab-resistant apple cultivars, there are also cultivars such as 'Reanda', 'Remo', 'Rene', 'Resi' and 'Rewena' which express a high degree of resistance to fire blight (Fischer \& Richter, 2004; Peil et al., 2009, 2020; Richter \& Fischer, 2002). In Switzerland, the new cultivar 'Ladina' with scab-resistance appeared tolerant also to fire blight and showed good productivity and fruit quality (Baumgartner et al., 2012; Kellerhals et al., 2017). Interestingly, this cultivar comes from the cross between 'Topaz' $\times$ 'Fuji', cultivars that are susceptible to fire blight. In addition, existing apple gene resources are being evaluated in the Czech Republic, Hungary and Poland (Sillerova et al., 2014; Sobiczewski et al., 2004, 2006, 2015; Toth et al., 2006). Research conducted in 2007-2009 as part of the European project Cost Action 864 regarding fire blight susceptibility assessment of 38 apple cultivars and clones from six countries (Belgium, Germany, Hungary, Poland, Sweden, Switzerland) revealed that clones Pi-As 12.53, Pi-As 50.74 and MR-10 possessed particularly high resistance (Sobiczewski et al., 2015). Based on leaf inoculation procedures, recently Kostick et al. (2019) evaluated 94 apple cultivars and important breeding parents and found that 16 of them (e.g. Aurora Golden Gala, Dolgo, Empire, Fireside, Frostbite) were highly resistant to E. amylovora infection.

Due to the quarantine status of E. amylovora in many countries (EPPO list A2) the assessment of susceptibility to fire blight is usually carried out in special greenhouse chambers or tunnels with appropriate conditions and by applying well established procedures. The most common methods are based on terminal shoot or leaf inoculation (Kostick et al., 2019; Peil et al., 2019; Sobiczewski et al., 2015). In nine tested apple genotypes Kellerhals et al. (2014) demonstrated that shoot inoculation in a greenhouse and tests with flower inoculation outdoors displayed similar susceptibility of these organs to fire blight. Moreover, through analysis of the genetic background of plant infection, Peil et al. (2019) confirmed that the strong QTL genomic region controlling fire blight resistance in the flowers of the $\mathrm{Mr} 5$ clone is located on LG3 as the one identified through shoot infection. In addition, very recent studies conducted by Emeriewen et al. (2021) underlined the presence of the region of interest (ROI) for fire blight resistance (FB)_Mar12 as the putative indicator of resistance from Malus $x$ arnoldiana, located on LG 12. Valuable information on the molecular basis of resistance to fire blight is provided by studies enabling the selection of donors of specific genomes, potentially related to regulation of this trait status. Since the resistance to disease is determined polygenically, the variability of new genotypes is an important element of targeted breeding, enabling the selection of the most valuable genotypes. The main genes involved in the resistance to fire blight have been identified and mapped on chromosomes III, V, VII, X and XII (represented by linkage groups LG3, LG5, LG7, LG10 and LG12) in the genomes of wild apple trees, such as Malus $\times$ robusta 5, Malus fusca, Malus floribunda 821, Malus $x$ arnoldiana, in ornamental cultivars such as 'Evereste', and in some other cultivars such as 'Fiesta', 'Discovery', and 'Florina' (Calenge et al., 2005; Durel et al., 2009; Emeriewen et al., 2021; Khan et al., 2006, 2007; Peil et al., 2007). Some small QTL regions were found to be present in LG8 of 'Royal Gala' and M. sieversii (GMAL 4593) mapping population (Desnoues et al., 2018).

Although in the apple breeding program of the National Institute of Horticultural Research (INHORT), Skierniewice, Poland, the selection of cultivars resistant to fire blight is not specifically targeted, almost each year newly-bred clones are tested for resistance to the disease. In the period 2016-2018, and for the first time in the last 20 years of testing numerous clones, we found that two out of the four recently bred expressed high levels of resistance and are of interest from a breeders as well as from a consumer point of view. In addition, DNA screening, using known molecular SSR and SCAR markers, allowing the initial characterization of new apple hybrid genotypes, is becoming a standard procedure in our current breeding programs (Keller-Przybyłkowicz et al., 2009).

The aim of presented study was the phenotypic and genetic assessment of susceptibility/resistance to fire blight of the new apple clones 'Early Szampion', J-2003-05, J9805-02 and 'Pink Braeburn' selected in INHORT.

\section{Material and methods}

Plant material and phenotypic evaluation

The trees of studied genotypes (Table 1) were produced each year in the winter period by hand grafting on M.9 
Table 1 The origin of studied genotypes

\begin{tabular}{|c|c|c|}
\hline No. & Genotype & 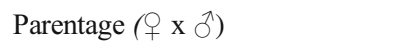 \\
\hline 1 & Early Szampion & 'Gold Milenium’ x ‘Šampion’ \\
\hline 2 & $\begin{array}{l}\text { Free Redstar - } \\
\quad \text { standard }\end{array}$ & $\begin{array}{l}\text { Unknown, selected at INHORT } \\
\text { from seedlings } \\
\text { obtained from seeds originating } \\
\text { from USA }\end{array}$ \\
\hline 3 & Idared - standard & 'Jonathan' x ‘Wagener' \\
\hline 4 & $\mathrm{~J}-2003-05$ & 'Melfree' x 'Sawa' \\
\hline 5 & J-9805-02 & 'Braeburn' x 'Pinova' \\
\hline 6 & Pink Braeburn & 'Braeburn' x 'Pinova' \\
\hline 7 & Šampion - standard & $\begin{array}{l}\text { 'Golden Delicious' x 'Cox } \\
\text { Orange' }\end{array}$ \\
\hline
\end{tabular}

rootstocks; then planted in containers with soil mixed with compost. In the spring, the potted plants were moved to a quarantine greenhouse. Each year, on the day of inoculation, the relative humidity was kept over $80 \%$ with temperatures (max./min.) of $21.9^{\circ} \mathrm{C} / 13.9^{\circ} \mathrm{C}$ in $2016,19.0^{\circ} \mathrm{C} / 13.6{ }^{\circ} \mathrm{C}$ in 2017 , and $22.6{ }^{\circ} \mathrm{C} / 7.8^{\circ} \mathrm{C}$ in the year 2018. During the study period the temperatures ranges were: in 2016 , from 13.7 to $19.3{ }^{\circ} \mathrm{C}$ in the night and from 20.1 to $24.73{ }^{\circ} \mathrm{C}$ during the day; in 2017 , from 13.4 to $19.8{ }^{\circ} \mathrm{C}$ in the night and from 18.7 to $25.9{ }^{\circ} \mathrm{C}$ during the day; and in 2018 , from 7.1 to $20.2^{\circ} \mathrm{C}$ in the night and from 20.4 to $26.7^{\circ} \mathrm{C}$ during the day. Inoculations of terminal shoots (in full vigor) were done by the method earlier described by Sobiczewski et al. (2004, 2006, 2015). This involved cutting off the tips below the first youngest unfolded leaf (close to apical meristem) with scissors, previously immersed in an aqueous suspension of E. amylovora strain Ea659, isolated from an apple shoot in Poland. The pathogenicity of the strain was checked every year of the study on the trees of the highly susceptible apple cultivar 'Idared'. To prepare the suspension, the bacteria were grown on sucrose nutrient agar (NSA, Difco Nutrient Agar 2.3\% and 5\% sucrose) at $24^{\circ} \mathrm{C}$ and after $24 \mathrm{~h}$ washed with sterile distilled water. The bacterial concentration $\left(10^{7} \mathrm{CFU} \mathrm{m}{ }^{-1}\right)$ was obtained by serial dilutions and the absorbance measured on a spectrocolorimeter (Semco S91E, Germany) at $630 \mathrm{~nm}$ wavelength (absorbance value 0.012 ). The strain was routinely stored in a mixture of PBS buffer with $20 \%$ glycerol at $-80{ }^{\circ} \mathrm{C}$.

Each genotype was represented by $20-32$ trees (2853 shoots). All inoculations were done within a single day. Inoculated shoots were immediately covered with plastic bags for $24 \mathrm{~h}$. Five genotypes were evaluated in 2016 (Fig. 1) and seven in each of 2017 and 2018 (Tables 3 and 4). Observations and measurements of necrotized part of shoots were made 1, 2 and 4 weeks after inoculations in 2016 and after 2, 4 and 6 weeks in the years 2017 and 2018. The length of necrotized part of shoots was expressed as percentage of the total length of shoots.

Shoot necrosis data were evaluated for homogeneity of variance using Levene's test. One-way ANOVA with the Brown-Forsythe correction for nonhomogeneous variances was used to test the overall mean difference hypothesis. For specific comparison of object averages, the nonparametric Games-Howell test was performed at $p=0.05$. For calculations, the STATISTICA v. 13 package (Dell Inc., 2016) and USERFRIENDLYSCIENCE v. 0.7.2 package (Peters, 2018) working in the R environment (R Core Team, 2019) were used.

\section{Genetic markers}

To confirm the genetic background of the phenotypic assessment of the selected genotypes, J-2003-05 and 'Early Szampion', showing high resistance to fire blight, the specific apple genome alleles corresponding to fire blight resistance were identified by 16 molecular markers, with known loci in the genome of M. domestica (Emeirewen et al., 2014; Emeriewen et al., 2021; Khan et al., 2006, 2007; Peil et al., 2007, 2009, 2019; van de Weg et al., 2018). The selected markers were subjected to applications for Marker Assisted Selection (MAS) procedures (Kellerhalls et al. 2012; Peil et al., 2019, 2020).

Identification of DNA fragments of these two genotypes was carried out. In addition, comparable analyses for their parental forms (cvs. 'Šampion', 'Sawa', 'Gold Milenium' and 'Melfree') were also performed. Genomic DNA was isolated from the selected plants by the method of Aldrich and Culis (1993). DNA template $(10 \mathrm{ng})$ was used for PCR tests to identify alleles of genes determining E. amylovora resistance. Sequences of representative microsatellite SSR markers $(\mathrm{CH} 03 \mathrm{e} 03$, CH03g12, AU223657, CH02a10, CH01f12, CH02b07, CH0 5 e 06 , FRMb32M04b, FRMb32M21, FRMb32M27, FR481A, FR367A) and SCAR markers (AE10, GE-8019, CH-Sd1, CHF7-Fb1), covering the regions regulating fire blight resistance of plants, identified on chromosomes III, V, VII X and XII of the Malus genome were used (Table 2). Amplification of 
Fig. 1 Apple terminal shoot susceptibility of 5 genotypes to fire blight after inoculation with Erwnia amylovora in 2016; means (means \pm SE) followed by the same letter do not differ significantly according to GamesHowell test at $p=0.05$; number of trees/shoots: Early Szampion 24/ 50, J-2003-05 24/48, Pink

Braeburn 25/44, J-9805-02 26/53, Šampion 30/32; susceptibility classes (Le Lezec et al., 1997): 0 no symptoms, 1 very low $(>0$ $20 \%), 2$ - low (>20-40\%), 3 moderate $(>40-60 \%), 4-$ high $(>60-80 \%), 5$ - very high $(>80$ $100 \%)$

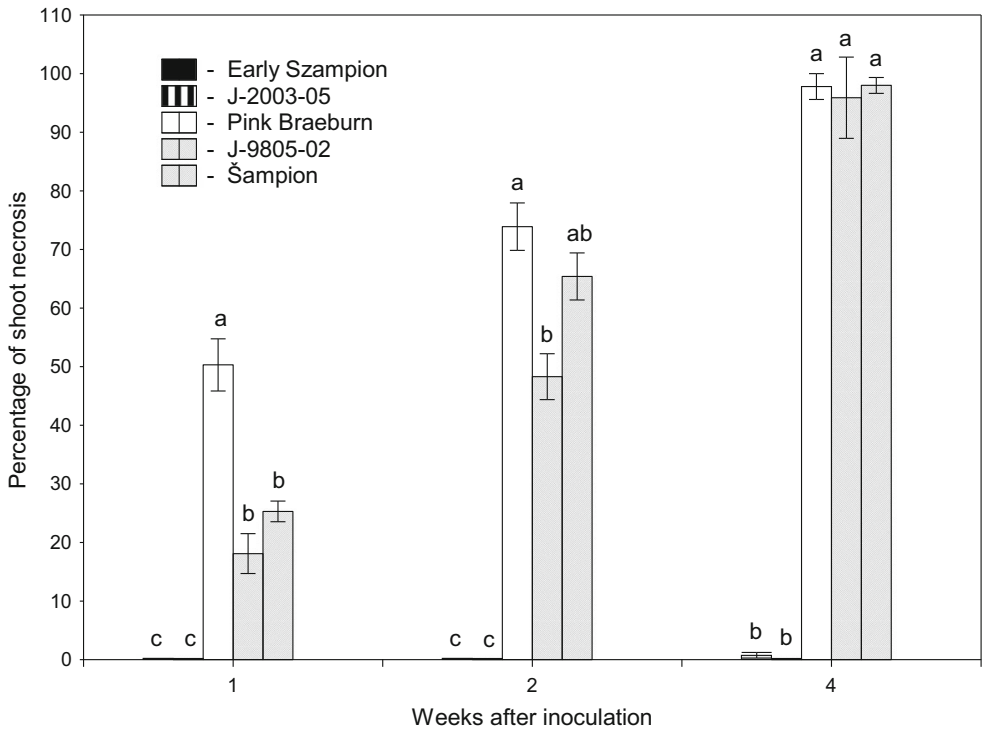

DNA fragments was carried out in a BIOMETRA Basic thermocycler in a $13 \mu \mathrm{l}$ reaction mixture containing: 10 ng DNA, 10x PCR buffer, $0.25 \mathrm{mM} \mathrm{MgCl}_{2}, 0.1 \mathrm{U}$ Taq Polymerase (Invitrogen), $10 \mathrm{mM}$ DTP [Applied Biosystem], $8 \mathrm{mM}$ of each primer, according to the optimized thermal profile. In case of SSR markers: the first four cycles were performed in the following thermal profile: $94^{\circ} \mathrm{C} / 30 \mathrm{~s}, 65^{\circ} \mathrm{C} / 90 \mathrm{~s}, 72^{\circ} \mathrm{C} / 120 \mathrm{~s}$, with the temperature of primer attachment decreased by $1{ }^{\circ} \mathrm{C}$ for each cycle. Then, a further 35 cycles were run at a constant primer annealing temperature $\left(60^{\circ} \mathrm{C} / 90 \mathrm{~s}\right)$. In the case of SCAR markers the PCR thermal conditions were as follows: $96^{\circ} \mathrm{C} / 45 \mathrm{~s}$, then 35 cycles at a constant temperature for primers annealing $60{ }^{\circ} \mathrm{C}$ (for primers: AE10, GE-8019, CH-F7-Fb1) and $63{ }^{\circ} \mathrm{C}$ (for primer $\mathrm{CH}-\mathrm{Sd} 1$ ) for $60 \mathrm{~s}$. Visualization of the PCR products was carried out under UV light, after electrophoretic separation in $1.8 \%$ agarose gel, stained with ethidium bromide (conc. $50 \mathrm{mg} / \mathrm{ml}$ ).

Statistical analysis and evaluation of genotype-phenotype correlation

The statistical analysis of genetic similarity (in terms of the dendrogram drawing) of all studied genotypes was undertaken using the AHC (Agglomerative Hierarchical Components) method - sharing of hierarchical components, weighted means (UPGMA) and Jacckard's correlation coefficient (XLStat 2006 program).
For the phenotypical assessment, a 4-fold level of plant replication was evaluated for each plants /shoot set at tree years (2016, 2017 and 2018) of susceptibility evaluation. Genetic data was represented by a $0-1$ matrix showing number of identified alleles in each plant. The genotype-phenotype correlation coefficient was calculated using TBCO STATISTICA 13.3 software, with the Spearman correlation coefficient set at the significance level $p=0.05$.

\section{Results}

Phenotypic assessment

Depending on the year of the study and the genotype, the first symptoms of the disease on the shoots in the form of slight browning around the inoculation sites appeared 3-4 days after inoculation. Sometimes they were accompanied with characteristic bacterial ooze. Observations and measurements made three times per year allowed the tracking of the dynamics of disease development. By comparing the size of shoot damage assessed 4 weeks after inoculation, it was found that genotypes J-2003-05 and 'Early Szampion' showed the highest disease resistance, while 'Pink Braeburn' and 'Šampion' showed the lowest. The percentage of necrotized parts of the shoots of the tested genotypes ranged from $0.7 \%$ ('Early Szampion') to $98.0 \%$ ('Šampion’) (Fig. 1, Table 3). Genotype J-2003-05 did 
Table 2 Molecular markers and estimated size of identified alleles in region of interests (ROI) of tested apple genotypes

\begin{tabular}{|c|c|c|c|c|}
\hline $\begin{array}{l}\text { Type and name of } \\
\text { molecular marker }\end{array}$ & Oligonucleotide sequence & Allele size $(b p)^{*}$ & Region of interest (ROI) & References \\
\hline SCAR - AE10 & $\begin{array}{l}\text { F:ctgaagcgcacgttctcc } \\
\text { R:ctgaagcgcatcattctgatag }\end{array}$ & $\underline{375}$ & LG 7 & Khan et al. 2006 \\
\hline SCAR - GE8019 & $\begin{array}{l}\text { F:ttgagaccgattttcgtgtg } \\
\text { R:tctctcccagagcttcattgt }\end{array}$ & $\underline{397}$ & LG 7 & Khan et al. 2007 \\
\hline SCAR - CHF7/Fb1 & $\begin{array}{l}F: \text { agccagatcacatgttttcat } \\
R: \text { acaacggccaccgtttatc }\end{array}$ & $\underline{210}$ & LG 7 & Khan et al. 2007 \\
\hline $\begin{array}{c}\text { SCAR - SD1 (associated } \\
\text { with aphid resistance) }\end{array}$ & $\begin{array}{l}\text { F:tgcgtatccaactcattctcc } \\
\text { R:gccataaaggaggtcgaatt }\end{array}$ & 120 & LG 7 & Khan et al. 2007 \\
\hline SSR - CH03g12 & $\begin{array}{l}\text { F:gcgctgaaaaaggtcagttt } \\
\text { R:caaggatgcgcatgtatttg }\end{array}$ & $\begin{array}{l}183,198 \\
220,280\end{array}$ & LG 3 & Liebhard et al. $2002 * *$ \\
\hline $\mathrm{SSR}-\mathrm{CH} 03 \mathrm{e} 03$ & $\begin{array}{l}\text { F:gcacattctgccttatcttgg } \\
\text { R:aaaacccacaaatagcgcc }\end{array}$ & $186, \overline{203}$ & LG 3 & Liebhard et al. $2002 * *$ \\
\hline SSR - AU223657 & $\begin{array}{l}F: \text { ttctccgtccccttcaacta } \\
\text { R:caccttgaggcctctgtagc }\end{array}$ & $\begin{array}{l}145,200, \\
212\end{array}$ & LG 3 & Silfverberg-Dilworth et al. 2006** \\
\hline $\mathrm{SSR}-\mathrm{CH} 02 \mathrm{a} 10$ & $\begin{array}{l}F: \text { atgccaatgcatgagacaaa } \\
R: \text { acacgcagctgaaacacttg }\end{array}$ & $\overline{\frac{177}{230}}, 200$ & LG 10 & Liebhard et al. $2002 * *$ \\
\hline $\mathrm{SSR}-\mathrm{CH} 01 \mathrm{f} 12$ & $\begin{array}{l}F: \text { ctcctccaagcttcaaccac } \\
R: \text { gcaaaaaccacaggcataac }\end{array}$ & 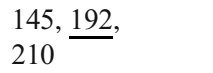 & LG 10 & Liebhard et al. $2002 * *$ \\
\hline $\mathrm{SSR}$ - CH02b07 & $\begin{array}{l}F: \text { ccagacaagtcatcacaacactc } \\
R: \text { atgtcgatgtcgctctgttg }\end{array}$ & $190, \underline{202}$ & LG 10 & Liebhard et al. $2002 * *$ \\
\hline $\mathrm{SSR}-\mathrm{CH} 05 \mathrm{e} 06$ & $\begin{array}{l}F: \text { acacgcacagagacagagacat } \\
R: \text { gttgaatagcatcccaaatggt }\end{array}$ & $155, \underline{187}$ & LG 5 & Liebhard et al. $2002 * *$ \\
\hline SSR -FRMb32M04b & $\begin{array}{l}F: \text { tggacaaattcagtgacacca } \\
R: \text { caaaccaccccaaattctgt }\end{array}$ & $\underline{194}, 228$ & LG 12 & Emeriewen et al. 2021 \\
\hline SSR - FRMb32M21 & $\begin{array}{l}F: \text { ttcttgcataatttgctctgtga } \\
R: \text { cagtggaggaaaggcaacat }\end{array}$ & $167, \underline{276}$ & LG 12 & Emeriewen et al. 2021 \\
\hline SSR - FRMb32M27 & $\begin{array}{l}F: \text { tttaattggctttcattcacg } \\
R: \text { aaggcgactcatgatttcgta }\end{array}$ & $130, \underline{160}$ & LG 12 & Emeriewen et al. 2021 \\
\hline SSR - FR481A & $\begin{array}{l}F \text { : cggaagcaaaaaggaacaaa } \\
R: \text { gccgtagtcttcgctctcac }\end{array}$ & $\underline{180}, 195$ & LG 10 & Emeriewen et al. 2014 \\
\hline SSR - FR367A & $\begin{array}{l}F: \text { tcccccaacacaaaatatgc } \\
R: \text { aaagggtcgagcagatcgta }\end{array}$ & $\frac{170}{215}, 178$ & LG 10 & Emeriewen et al. 2014 \\
\hline
\end{tabular}

* underlined alleles are potentially correlated with fire blight resistance

** information for applied SSR alleles with predicted molecular size range

not show disease symptoms in the test in 2016 and only poor symptoms in tests performed in 2017 and 2018. As expected, the standard cv. 'Idared' tested in 2017 and 2018 was included in the group of very highly susceptible genotypes. The genotype J-9805-02 deserves special attention, within the first week after inoculation in 2016 it showed low susceptibility but three weeks later it showed very high susceptibility. In 2017 this genotype appeared to be highly susceptible and in 2018 very highly susceptible.

The assessment of the susceptibility of the genotypes tested in 2017 and 2018, 6 weeks after inoculation, again showed the highest resistance for genotypes J2003-05 and 'Early Szampion', with the percentage of the affected part of the shoots in the former from 6.0 to
$11.2 \%$, and in the latter from 8.4 to $13.7 \%$. The following three of the other four genotypes: 'Idared', 'Šampion' and 'Pink Braeburn', were rated as highly susceptible in both years. In 2017 'Free Redstar' was determined as low susceptiblity (percentage of the affected part of shoots 31.9\%); in 2018 this cultivar was classified as very low susceptibility (3.9\%).

Interesting data was obtained by the analysis of the susceptibility of individual shoots of the studied genotypes (disease incidence on shoots) performed 4 weeks after inoculation in 2016 and 6 weeks after inoculation in 2017 and 2018 (Table 4). In the case of genotypes J2003-05 and 'Early Szampion' no symptoms were observed in $100 \%$ and $92 \%$ respectively of the shoots inoculated in 2016, whereas in the case of 'Pink 


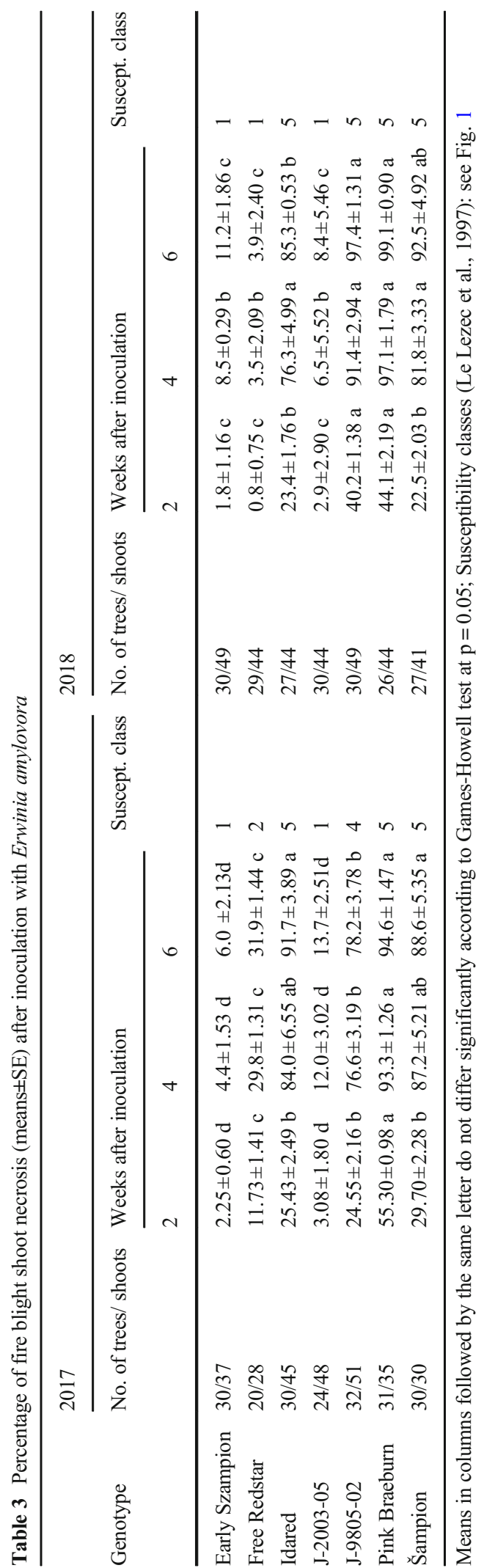

Braeburn', J-9805-02 and 'Šampion” tested in the same year only $2.2,5.7$ and $3.1 \%$ respectively of the shoots showed symptoms. The results in 2017 and 2018 indicate similar trends. For genotypes J-2003-05 and 'Early Szampion' no disease symptoms were found in $83.8 \%$ and $77.0 \%$ of shoots assessed in 2017 , and in $87.8 \%$ and $77.3 \%$ of the shoots assessed in 2018 , respectively. It should be also noted that the assessment carried out in 2017 showed that for these genotypes respectively $10.8 \%$ and $6.25 \%$ of shoots were very strongly infested (class 5). In 2018, only $4.5 \%$ of shoots were similarly infected in genotype 'Early Szampion' but in J-2003-05 there were no strongly infected shoots.

The most consistent results were obtained for 'Pink Braeburn' with $97.8,88.9$ and $97.7 \%$ of highly infested shoots in the individual years. Similar results were obtained for cv. 'Šampion', 96.9, 85.7 and 88.4\%. However, in the case of 'Idared' in $2018,63.3 \%$ of shoots proved to be very susceptible and $34.7 \%$ susceptible (Table 4). Particular attention should be paid to cv. 'Free Redstar', in which the assessment in 2017 showed no disease symptoms in only $42.9 \%$ of shoots and in $32.1 \%$ of highly infested shoots; in 2018 as much as $84.4 \%$ of shoots did not show disease symptoms and there were no shoots strongly or very seriously infested (Table 4).

Genetic status of selected apple cultivars and clones

The molecular assessment of tested apple genotypes to fire blight resistance showed different number of specific amplicons associated with the trait (5-13 alleles) (Table 5). Their analysis allowed the characterization of susceptible genotypes in which only 5-7 alleles of resistance genes (originating from linkage groups LG3, LG7 LG 10 and LG12 of the Malus genome) were identified, i.e. cvs. 'Gold Millenium' 'Šampion' and 'Melfree', as well as highly resistant genotypes in which 10-13 DNA amplicons associated with fire blight resistance were detected, i.e. J-2003-05 (10 alleles), cv. 'Early Szampion' (10 alleles) and cv. 'Sawa' (13 alleles). In comparison to the genomes of parental cultivars 'Šampion' and 'Gold Millenium', a higher number of resistance alleles was noted for 'Early Szampion'. Based on the constructed dendrogram it was possible to conclude that the potential donor of allele resistance for clone J-2003-05 was 'Melfree', whereas for 'Early Szampion' it was 'Gold Millenium'. The most genetically distant cultivars were 'Gold Millennium' and 'Szampion' (Fig. 2). 
Table 4 Distribution of fire blight incidence (in \%) on apple shoots among susceptibility classes four or six weeks after inoculation with Erwinia amylovora

\begin{tabular}{|c|c|c|c|c|c|c|c|c|c|c|c|c|c|c|c|c|c|c|}
\hline \multirow{3}{*}{ Genotype } & \multicolumn{18}{|c|}{ Susceptibility classes } \\
\hline & \multicolumn{6}{|l|}{2016} & \multicolumn{6}{|l|}{2017} & \multicolumn{6}{|l|}{2018} \\
\hline & $\begin{array}{l}\text { No } \\
\text { symptoms }\end{array}$ & 1 & 2 & 3 & 4 & 5 & $\begin{array}{l}\text { No } \\
\text { symptoms }\end{array}$ & 1 & 2 & 3 & 4 & 5 & $\begin{array}{l}\text { No } \\
\text { symptoms }\end{array}$ & 1 & 2 & 3 & 4 & 5 \\
\hline Early Szampion & 92 & 0 & 0 & 0 & 0 & 8 & 77.0 & 14.6 & 0 & 2.1 & 0 & 6.3 & 77.3 & 9.1 & 2.3 & 0 & 6.8 & 4.5 \\
\hline Free Redstar & nd & nd & nd & nd & nd & nd & 42.9 & 14.3 & 0 & 3.6 & 7.1 & 32.1 & 84.4 & 8.9 & 2.2 & 4.4 & 0 & 0 \\
\hline Idared & nd & nd & nd & nd & nd & nd & 9.8 & 2.0 & 0 & 0 & 0 & 88.2 & 0 & 0 & 0 & 2.0 & 34.7 & 63.3 \\
\hline $\mathrm{J}-2003-05$ & 100 & 0 & 0 & 0 & 0 & 0 & 83.8 & 5.4 & 0 & 0 & 0 & 10.8 & 87.8 & 2.0 & 0 & 4,1 & 6.1 & 0 \\
\hline J-9805-02 & 5.7 & 0 & 0 & 0 & 1.9 & 92.4 & 23.3 & 3.3 & 3.3 & 0 & 3.3 & 66.7 & 0 & 0 & 0 & 2.4 & 2.4 & 95.1 \\
\hline Pink Braeburn & 2.2 & 0 & 0 & 0 & 0 & 97.8 & 6.7 & 0 & 2.2 & 0 & 2.2 & 88.9 & 0 & 0 & 0 & 0 & 2.3 & 97.7 \\
\hline Šampion & 3.1 & 0 & 0 & 0 & 0 & 96.9 & 8.6 & 2.9 & 0 & 0 & 2.9 & 85.7 & 6.8 & 0 & 0 & 0 & 6.8 & 86.4 \\
\hline
\end{tabular}

Susceptibility classes (Le Lezec et al., 1997) see Fig. 1, 2016 - evaluation was done 4 weeks after inoculation; nd - not done

The estimated correlation coefficient value between phenotypic plant assessment and number of identified alleles in evaluated apple genotypes showed a high significant negative correlation between the observed plant response to E. amylovora inoculation (low percentage of shoot infestation) and number of identified alleles for fire blight resistance (high allele number). The correlation coefficient level ranged between -0.763 and -0.997 depending on the year of plant evaluation (Table 6).

\section{Discussion}

The results of this 3-year research program, conducted in similar but not identical conditions in each year, in most cases indicate high similarity in the susceptibility to fire blight of the tested genotypes in the individual years. An important breeding achievement is that genotypes J2003-05 and 'Early Szampion' which are characterized as very highly resistant to fire blight. This is also confirmed by the results of molecular studies indicating the presence of $10 \mathrm{FB}$ alleles located in ROI represented by linkage groups 3, 5, 7, 10 and 12 of the Malus genome, respectively, detected in both genotypes evaluated. Genotype J-2003-05, was derived from the crossing of 'Melfree' and 'Sawa' which on the basis of our earlier studies were determined as of moderate (3rd) and low susceptibility (2nd). 'Early Szampion' was derived from the crossing of 'Gold Millenium' and 'Šampion', both classified as very susceptible (Sobiczewski et al., 2004, 2006, 2015, Sobiczewski, unpublished data).
Bright red, large and attractive fruits of 'Early Szampion' ripen at the turn of August and September, which distinguishes it from the standard cultivar 'Šampion'. The clone J-2003-05 is characterized by very large, dark red and tasty fruit (Lewandowski et al., 2016; Lewandowski et al., 2018). The appearance and taste features together with demonstrated high resistance to fire blight of genotypes J-2003-05 and 'Early Szampion' are expected to meet the quality preferences of the consumers and the overall production value. Assessment of apple genotypes for susceptibility to fire blight was based on the results obtained following shoots inoculation with strain Ea659, routinely used in this type of our research. Inoculations with a highly virulent strain of the pathogen has also been commonly used in similar studies (Harshman et al., 2017; Kellerhals et al., 2012; Kellerhals et al., 2017; Kostick et al., 2019; Peil et al., 2019; Sobiczewski et al., 2004, 2006, 2015). However, the possibility of differential interaction between various strains of E. amylovora and apple cultivars should be taken into consideration (Emeriewen et al., 2019; Norelli et al., 1984). Some authors point out the possibility of different host plant and pathogen interactions depending on the strain used, including its origin (Khan et al., 2018; Norelli et al., 1984; Paulin \& Lespinasse, 1990; Puławska \& Sobiczewski, 2012). Also, the type of inoculum, a single strain or mixture of the strains, may be relevant (Bell et al., 1990; Emeriewen et al., 2019; Norelli et al., 1984; Paulin \& Lespinasse, 1990; Peil et al., 2009). 
Table 5 Distribution of alleles detected in the genome region of interest (ROI), involved in fire blight resistance of studied apple cultivars and clones

\begin{tabular}{|c|c|c|c|}
\hline Genotype & $\begin{array}{l}\text { Total number of identified } \\
\text { resistance alleles in ROI/ } \\
\text { plant molecular status }\end{array}$ & $\begin{array}{l}\text { Number of identified alleles } \\
\text { with regard to molecular } \\
\text { markers covering ROI } \\
\text { LG/ alleles }\end{array}$ & Phenotypic susceptiblity \\
\hline $\begin{array}{l}\text { Early Szampion } \\
\text { (‘Šampion’ x Gold Milenium’) }\end{array}$ & 10 & $\begin{array}{l}\text { LG } 3 / 2 \\
\text { LG 7/3 } \\
\text { LG 10/ } 2 \\
\text { LG 12/ } 3\end{array}$ & 1 \\
\hline Gold Milenium & 5 & $\begin{array}{l}\text { LG 3/ } 2 \\
\text { LG 7/ } 1 \\
\text { LG 10/ } 1 \\
\text { LG12/ } 1\end{array}$ & $5,4^{3}$ \\
\hline $\begin{array}{l}\mathbf{J} / \mathbf{2 0 0 3 / 0 5} \\
\text { ('Melfree x Sawa') }\end{array}$ & 10 & $\begin{array}{l}\text { LG 3/3 } \\
\text { LG 5/ } 1 \\
\text { LG 7/ } 2 \\
\text { LG 10/2 } \\
\text { LG 12/ } 2\end{array}$ & 1 \\
\hline Melfree & 6 & $\begin{array}{l}\text { LG 3/ } 1 \\
\text { LG 7/ } 1 \\
\text { LG 10/ } 1 \\
\text { LG12/ } 3\end{array}$ & $3^{1,2} 5,4^{3}$ \\
\hline Sawa & 13 & $\begin{array}{l}\text { LG 3/3 } \\
\text { LG 5/ } 1 \\
\text { LG 7/ } 3 \\
\text { LG 10/4 } \\
\text { LG12/ } 2\end{array}$ & $2^{2}$ \\
\hline Šampion & 7 & $\begin{array}{l}\text { LG } 3 / 3 \\
\mathrm{LG} 7 / 1 \\
\mathrm{LG} 12 / 3\end{array}$ & 5 \\
\hline
\end{tabular}

\footnotetext{
${ }^{1}$ Sobiczewski et al. (2004), ${ }^{2}$ Sobiczewski et al. (2006), ${ }^{3}$ Sobiczewski et al. (2015); Phenotypic susceptibility: susceptibility classes (Le Lezec et al., 1997): 0 / no symptoms, 1 very low (0/20\%), 2 - low (>20/40\%), 3 - moderate $(>40 / 60 \%), 4-$ high $(>60 / 80 \%), 5-$ very high $(>80 / 100 \%)$
}

In this context it is worth mentioning the previous results of the phenotypic evaluation of the susceptibility of shoots of various apple cultivars and clones to fire blight carried out within the frame of the COST 864 action in Poland (INHORT) and Germany (JKI). Of the 25 apple genotypes tested in both countries, 17 showed the same or similar susceptibility to fire blight, although different organs were inoculated (INHORT: shoots, JKI: leaves), as well as when different inoculum (single strain or mixture) were used (Sobiczewski et al., 2015). Additional comparative analysis to determine the significance of the type of inoculum tested on shoots of apple cultivars with different susceptibility ('Enterprise',
'Idared', 'Spartan', 'Free Redstar') using the abovementioned methods of inoculation showed no significant differences in the severity of the disease in individual cultivars (Sobiczewski et al., 2015).

Various authors emphasize the importance of the impact of environmental conditions on the efficiency of inoculation. Infection usually occurs at ambient temperatures ranging between 21 and $27^{\circ} \mathrm{C}$ but can occur also at temperatures between 18.5 and $32-35^{\circ} \mathrm{C}$. In addition, high relative air humidity favors the development of the disease (van der Zwet et al., 2012). The analysis of conditions during the period of our research indicates that they were conducive to both infection and 
Fig. 2 Genetic distance between parental forms and their hybrid genotypes, corresponding to allele diversity among the studied genome region of interest (ROI) (linkage groups)

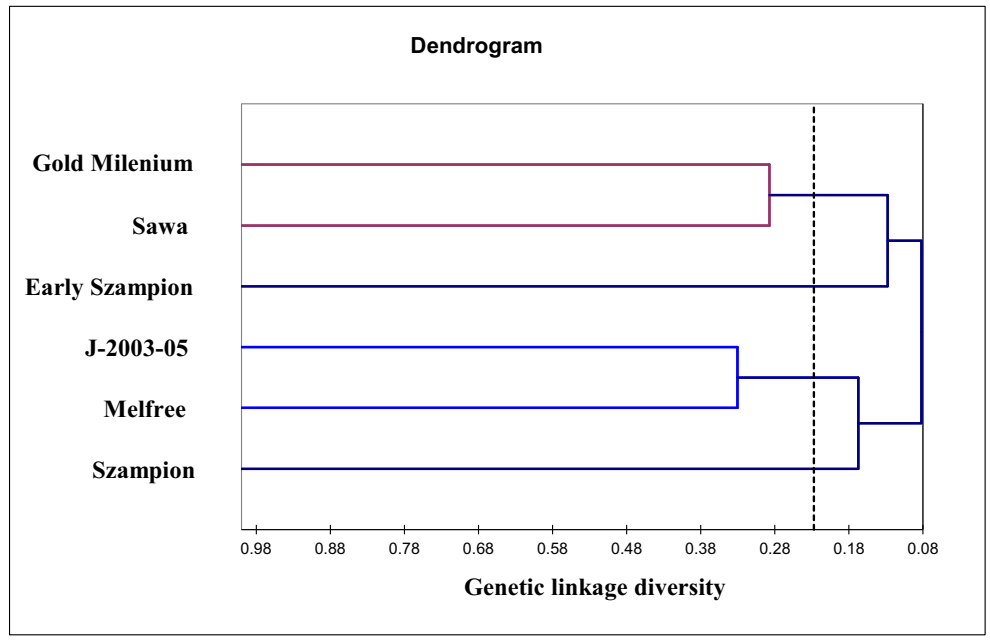

the development of the disease. Richter and Fischer (2002) drew attention to the importance of weather conditions, especially temperature, when conducting this type of research.

The choice of shoots for inoculation is also important. Fully vigorous shoots are more susceptible to disease, while shoots that grow weakly or those that have already completed growth are more resistant (Hepaksoy et al., 1999; Ozrenk et al., 2012). Harshman et al. (2017) also noticed that the susceptibility of shoots to fire blight depends on their vigor and physiological condition. Some genotypes of Malus sieversii showed shoot resistance when artificially inoculated, while they proved susceptible to natural infection.

Particularly noteworthy is the cultivar 'Free Redstar'. Our previous research allowed this cultivar to be classified as of low susceptibility (Sobiczewski et al., 2004). Also, the assessment carried out at JKI showed that it is a low susceptible genotype (Sobiczewski et al., 2015). However, in other studies this cultivar was classified as of very low susceptibility (Sobiczewski et al., 2006;
Sobiczewski et al., 2015). Due to the relatively large percentage of shoots infected in 2017 (32.1\% in class 5), it should be concluded that the susceptibility trait of this cultivar may be not stable.

The results of our molecular study confirmed the polygenic nature of apple resistance to fire blight and the close relationship between the degree of their susceptibility after shoot inoculation by E. amylovora and the number of identified alleles of resistance genes. Cumulative analysis of phenotype - genotype data showed significant correlation between the susceptibility class of selected plants and numbers of genetic alleles present in their genomes. One of the priorities in breeding programs for development of disease resistant genotypes is the 'pyramiding' of gene alleles of important functional traits, including resistance to fire blight (Kellerhals et al., 2013). It's well known that the presence of favorable alleles may not confer total resistance of plants (Peil et al., 2020). Moreover, the analysis of the population of hybrid plants derived from most distant parents regarding the trait of interest, may give

Table 6 Phenotype-genotype correlation calculated for analyzed apple accessions

\begin{tabular}{|c|c|c|c|c|}
\hline \multirow[t]{2}{*}{ Year of phenotypical assessment } & \multicolumn{4}{|c|}{$\begin{array}{l}\text { Spearman's rank order correlation, } \\
\text { correlation coefficients are significant with } p<0.05\end{array}$} \\
\hline & 2016 & 2017 & 2018 & Correlation value \\
\hline 2016 & $\mathrm{x}$ & $0.931 * *$ & $0,89 * *$ & $-0.763 * *$ \\
\hline 2017 & $0.931 * *$ & $\mathrm{x}$ & $0,87 * *$ & $-0.96 * *$ \\
\hline 2018 & $0.89 * *$ & $0.87 * *$ & $\mathrm{x}$ & $-0.997 * *$ \\
\hline
\end{tabular}

$\mathrm{x}$ - $(p$ value $=1)$ correlation coefficient between the same year of evaluation

** level of significance between number of resistance alleles and the level of shoot symptoms 
information about the allele distribution and the inheritance potential of resistance genome fragments. Since many mapping populations of Malus were evaluated and genomic regions concerning QTLs (Quantitative Trait Loci) have been widely estimated, in the present study we focused on the application of markers belonging to the precise ROI useful for Marker Assisted Selection (MAS). This technique allowed us to verify the genetic status of phenotyped plants and conferred the usefulness of selected genotypes J-2003-05 and 'Early Szampion' as good donors of fire blight resistance.

It is worth mentioning, that the pilot studies also indicated that the selected genotype 'Early Szampion' contains more alleles (10) of resistance than its parental forms 'Šampion' (7) and 'Gold Millenium' (5). Also, the second highly resistant genotype J-2003-05 possessed 10 resistant alleles and its parental forms: cultivars 'Sawa' and 'Melfree' 13 and 6 such alleles, respectively. This may confirm that some cultivars are very good donors of favorable alleles appearing in hybrid genotypes, which is as mostly needed in breeding programs. In our study we have observed the allele accumulation in the hybrid genotypes. Earlier, a similar phenomenon was also observed in the case of newly developed cultivar 'Ladina' (Kellerhals et al., 2017). Although crossed cultivars do not represent a high degree of resistance to fire blight, the accumulation of alleles, observed in the hybrid genotype, significantly influenced the phenotype of the newly generated apple cultivar. Simultaneously, after submission of various sources of resistance, including backcross populations, Kellerhals et al. (2017) observed the acceleration of gene introgression from wild varieties, contributing to increased resistance of progeny genotypes obtained only by crossing of commercial cultivars with wild species.

In general, molecular markers have been successfully used for identification of desired plant traits as well as for marker assisted selection (MAS, Marker Assisted Selection) (Le Roux et al., 2010, Kellerhals et al., 2017). Co-localization of ROI with putative resistant genes suggests that some genomic regions are strongly involved in pathogen recognition (Calenge et al., 2004; Khan et al., 2006). Additional clusters of resistance gene analogues (RGAs), linked to the major ROI, controlling the intensity of the defense reactions in plants were found by Calenge and Durell (2006). Moreover, many factors such as pathogenesis-related proteins (PR) and gene transcripts can enhance resistance in host plants (Ko et al., 2000; Malnoy et al., 2003, 2005). These may routinely be used in resistance breeding programs for screening of newly developed apple cultivars (Baldo et al., 2010; Bonasera et al., 2006). Since the analysis of potential ROI were limited to genetic assessment of only the most favorable genotypes from different apple breeding programs, we focused only on the identification of putative amplicons of alleles contributing in trait origin. Therefore, potential distribution of marker loci were estimated, without likelihood level verification, by taking into account the reports of Peil et al. (2020) and Kellerhals et al. (2017) on significantly high levels of molecular marker transferability within genotypes. The reported study provided valuable information about the presence of fire blight resistance alleles and confirmed the usefulness of those markers to the early information on the newly bred apple genotypes being potentially resistant cultivars. We also emphasize that our study indicates that the level of fire blight resistance seems to be strictly correlated with the number of alleles present in evaluated apple genomes. This assumption is in accordance with the findings of Peil et al. (2009); Baumgartner at al. (2015) and Emeriewen et al. (2021) for the main goal of pyramiding in breeding for resistance.

Author contribution statement PS designed the study, conducted a phenotypic assessment in two years, compiled results, prepared part of manuscript; SKP conducted molecular assessment, collated and compiled the results, constructed the dendrogram, prepared part of manuscript; ML produced trees and took care of them during study, AM conducted a phenotypic assessment in one year; RM performed statistical analysis.

Funding This work was supported the Multi-Annual Program of Polish Ministry of Agriculture and Rural Development (2014 2020).

\section{Declarations}

Conflict of interest The authors declare no conflict of interest.

Open Access This article is licensed under a Creative Commons Attribution 4.0 International License, which permits use, sharing, adaptation, distribution and reproduction in any medium or format, as long as you give appropriate credit to the original author(s) and the source, provide a link to the Creative Commons licence, and indicate if changes were made. The images or other third party material in this article are included in the article's Creative Commons licence, unless indicated otherwise in a credit line to the material. If material is not included in the article's Creative 
Commons licence and your intended use is not permitted by statutory regulation or exceeds the permitted use, you will need to obtain permission directly from the copyright holder. To view a copy of this licence, visit http://creativecommons. org/licenses/by/4.0/.

\section{References}

Aldrich, J., \& Culis, C. A. (1993). RAPD analysis in flax: Optimization of yield and reproducibility using KlenTag 1 DNA polymerase, Chelex 100, and gel purification of genomic DNA. Plant Mol Biol Repository, 11, 128-141.

Aldwinckle, H. S., Gustafson, H. L., \& Forsline, P. L. (1999). Evaluation of the core subset of the USDA apple germplasm collection for resistance to fire blight. Acta Horticulturae, 489, 269-272.

Baldo, A., Norelli, J. L., Farrell Jr., R. E., Bassett, C. L., Aldwinckle, H. S., \& Malnoy, M. (2010). Identification of genes differentially expressed during interaction of resistant and susceptible apple cultivars (Malus $\times$ domestica) with Erwinia amylovora. BMC Plant Biology, 10, 1. https://doi. org/10.1186/1471-2229-10-1.

Baumgartner, I., Leumann, L.R., Frey, J.E., Joos, M., Voegele, R.T., \& Kellerhals M. (2012). Breeding apples to withstand infection pressure by fire blight and other diseases. Proceedings of the 15th Int Conf org fruit-growing. Hohenheim, Germany, 20-22 February 2012, 14-21.

Baumgartner, I. O., Patocchi, A., Frey, J. E., Peil, A., \& Kellerhals, M. (2015). Breeding elite lines of apple carrying pyramided homozygous resistance genes against apple scab and resistance against powdery mildew and fire blight. Plant Molecular Biology Reporter, 33(5), 1573-1583.

Bell, R. L., van der Zwet, T., Bonn, W., Thibault, B., \& Lecomte, P. (1990). Environmental and strain effects on screening for fire blight resistance. Acta Horticulturae, 273, 343-350.

Bonasera, J. M., Kim, J. F., \& Beer, S. V. (2006). PR genes of apple: Identification and expression in response to elicitors and inoculation with Erwinia amylovora. BMC Plant Biology, 6, 23-35.

Calenge, F., \& Durell, C. E. (2006). Both stable and unstable QTLs for resistance to powdery mildew are detected in apple after four years of field assessment. Molecular Breeding, 17, 329-339.

Calenge, F., Faure, A., Goerre, M., Gebhart, C., van de Weg, W. E., Parisi, L., \& Durell, C. E. (2004). Quantitative trait loci (QTL) analysis reveals both broad-spectrum and isolatespecific QTL for scab resistance in an apple progeny challenged with eight isolates of Venturia inaequalis. Phythopathology, 4(94), 370-379.

Calenge, F., Drouet, D., Denance, C., van de Weg, W. E., Brisset, M. N., Paulin, J. P., \& Durel, C. E. (2005). Identification of a major QTL together with several minor additive or epistatic QTLs for resistance to fire blight in apple in two related progenies. Theoretical and Applied Genetics, 111, 128-135.

Dell Inc. (2016). Dell Statistica (data analysis software system), version 13. software.dell.com.
Desnoues E., Norelli J.L., Aldwinckle H.S, Wisniewski M., Evans K.M, Malnoy M., Khan A. (2018) Identification of novel strain-specific and environment-dependent minor QTLs linked to fire blight resistance in apples. Plant Molecular Biology Reporter 36, 247-256.

Durel, C. E., Denancé, C., \& Brisset, M. N. (2009). Two distinct major QTL for resistance to fire blight co-localize on linkage group 12 in apple genotypes 'Evereste' and Malus floribunda clone 821. Genome, 52(2), 139-147.

Emeirewen, O., Richter, K., Kilian, A., Zini, E., Hanke, M.-W., Malnoy, M., \& Peil, A. (2014). Identification of a major quantitative locus for resistance to fire blight in the wild apple species Malus fusca. Mol Breeding, 34, 407-419. https://doi. org/10.1007/s11032-014-0043-1.

Emeriewen, O.F., Wohener, T., Flachowsky, H., \& Peil, A. (2019). Malus hosts-Erwinia amylovora interactions: Strain pathogenicity and resistance mechanisms. Frontiers in Plant Science 551. https://doi.org/10.3389/fpls.2019.00551, 10.

Emeriewen, O. F., Richter, K., Flachowsky, H., Malnoy, M., \& Peil, A. (2021). Genetic analysis and fine mapping of the fire blight resistance locus of Malus $x$ arnoldiana on linkage group 12 reveal first candidate genes. Frontiers in Plant Science, 20. https://doi.org/10.3389/fpls.2021.667133.

Fischer, C., \& Richter, K. (2004). Fire blight resistance apple cultivars produced by conventional breeding. Acta Horticulturae, 663, 721-724.

Harshman, J. M., Evans, K. M., Allen, H., Potts, R., Flamenco, J., Aldwinckle, H. S., Wisniewski, M. E., \& Norelli, J. L. (2017). Fire blight resistance in wild accessions of Malus sieversii. Plant Disease, 101, 1738-1745.

Hepaksoy, S., Unal, A., Can, H. Z., Saygili, H., \& Turkusay, H. (1999). Distribution of fire blight (Erwinia amylovora) (Burrill) Winslow et al.) disease in Western Anatolia region in Turkey. Acta Horticulturae 489, 193-197.

Kellerhals, M., Franck, L., Baumgartner, I. O., Patocchi, A., \& Frey, J. E. (2011). Breeding for fire blight resistance in apple. Acta Horticulturae, 896, 385-390.

Kellerhals, M., Szalatnay, D., Hunziker, K., Duffy, B., Nybom, H., Ahmadi-Afzadi, M., Höfer, M., Richter, K., \& Lateur, M. (2012). European pome fruit genetic resources evaluated for disease resistance. Trees, 26, 179-189.

Kellerhals, M., Baumgartner, I. O., Leumann, L., Frey, J. E., \& Patocchi, A. (2013). Progress in pyramiding disease resistances in apple breeding. Acta Horticulturae, 976, 487-491.

Kellerhals, M., Baumgartner, I. O., Leumann, L., Lussi, L., Schütz, S., \& Patocchi, A. (2014). Breeding high quality apples with fire blight resistance. Acta Horticicult, 1056, 225-230.

Kellerhals, M., Schütz, S., \& Patocchi, A. (2017). Breeding for host resistance to fire blight. J Plant Path, 99(Special issue), 37-43.

Keller-Przybyłkowicz, S., Lewandowski, M., \& Korbin, M. (2009). Molecular screening of apple (Malus domestica) cultivars and breeding clones for their resistance to fire blight. J Fruit Ornam Plant Res, 17(2), 31-43.

Khan, M. A., Duffy, B., Gessler, C., \& Patocchi, A. (2006). QTL mapping of fire blight resistance in apple. Molecular Breeding, 17, 299-306. https://doi.org/10.1007/s11032006-9000-y.

Khan, M. A., Durel, C. E., Duffy, B., Drouet, D., Kellerhals, M., Gessler, C., \& Patocchi, A. (2007). Development of molecular markers linked to the 'fiesta' linkage group 7 major QTL 
for fire blight resistance and their application for marker assisted selection. Genome., 50, 568-577.

Khan, A., Desnoues, E., \& Clark, M. (2018). Bacterial strain affects cultivar response to fire blight in apples. Fruit Quarterly, 26(2), 15-20.

Ko, K., Norelli, J. L., Reynoird, J. P., Borejsza-Wysocka, E., Brown, S. K., \& Aldwinckle, H. S. (2000). Effect of untranslated leader sequence of AVM RNA 4 and signal peptide of pathogenesis-related proteins $1 \mathrm{~b}$ attacin gene expression, and resistance to fire blight in transgenic apple. Biotech. Letters, 22, 373-381.

Kostick, S. A., Norelli, J. L., \& Evans, K. M. (2019). Novel metrics to classify fire blight resistance of 94 apple cultivars. Plant Pathology, 68, 985-996.

Le Roux, P.-M., Khan, M. A., Broggini, G. A., Duffy, B., Gessler, C., \& Patocchi, A. (2010). Mapping of quantitative trait loci for fire blight resistance in the apple cultivars 'Florina' and 'Nova Easygro'. Genome, 53, 710-722.

Lespinasse, Y., \& Aldwinckle, H. S. (2000). Breeding for resistance to fire blight. In J. L. Vanneste (Ed.), Fire blight: The disease and its causative agent, Erwinia amylovora (pp. 253-273). CABI Publishing.

Lewandowski, M., Żurawicz, E., \& Kubik, J. (2016). Wstępna ocena wartości produkcyjnej nowych polskich odmian jabłoni na różnych typach podkładek wegetatywnych. Zeszyty Naukowe Instytutu Ogrodnictwa, 24, 91-98 (in Polish with English abstract).

Lewandowski, M., Żurawicz, E., Kubik, J., \& Strojny, K. (2018). Wstępna ocena wartości produkcyjnej nowych klonów jabłoni hodowli Instytutu Ogrodnictwa. Zeszyty Naukowe Instytutu Ogrodnictwa, 26, 45-56 (in Polish with English abstract).

Liebhard, R., Gianfranceschi, L., Koller, B., Ryder, C. D., Tarchini, R., van de Weg, E., \& Gessler, C. (2002). Development and characterization of 140 new microsatelites in apple (Malus $\times$ domestica Borkh.). Molecular Breeding, 10, 217-241.

Malnoy, M., Venisse, J. S., Brisset, M. N., \& Chevreau, E. (2003). Expression of bovine lactoferrin cDNA confers resistance to Erwinia amylovora in transgenic pear. Molecular Breeding, 12, 231-244.

Malnoy, M., Faize, M., Venisse, J. S., Geider, K., \& Chevreau, E. (2005). Expression of viral EPS-depolymerase reduces fire blight susceptibility in transgenic pear. Plant Cell Reports, 23, 632-638.

Norelli, J. L., Aldwinckle, H. S., \& Beer, S. V. (1984). Differential host $\mathrm{x}$ pathogen interactions among cultivars of apple and strains of Erwinia amylovora. Phythopathology, 76, 136139.

Norelli, J. L., Jones, A. L., \& Aldwinckle, H. S. (2003). Fire blight management in the twenty-first century using new technologies that enhance host resistance in apple. Plant Disease, 87, 756765.

Ozrenk, K., Balta, F., \& Celik, F. (2012). Levels of fire blight (Erwinia amylovora) susceptibility of native apple, pear and quince germplasm from Lake Van Basin, Turkey. European Journal of Plant Pathology, 132, 229-236.
Paulin, J. P., \& Lespinasse, Y. (1990). Pathogenicity of strains of Erwinia amylovora to some apple cultivars in the greenhouse. Acta Horticulturae, 273, 319-326.

Peil, A., Garcia-Libreros, T., Ritcher, K., Trognitz, F. C., Trognitz, B., Hanke, M. V., \& Flachovsky, H. (2007). Strong evidence for fire blight resistance gene of Malus robusta located on linkage group 3. Plant Breeding, 126, 470-475.

Peil, A., Bus, V. G. M., Geider, K., Richter, K., Flachowsky, H., \& Hanke, M. V. (2009). Improvement of fire blight resistance in apple and pear. Int J Plant Breed, 3, 1-27.

Peil, A., Hübert, C., Wensing, A., Horner, M., Emeriewen, O. F., Richter, K., Wohner, T., Chagne, D., Orellana-Torrejon, C., Saeed, M., Troggio, M., Stefani, E., Gardiner, S. E., Hanke, M. V., Flachowsky, H., \& Bus, V. G. M. (2019). Mapping of fire blight resistance in Malus x robusta 5 flowers following artificial inoculation. BMV Plant Biol, 19, 532.

Peil, A., Emeriewen O.F., Khan, A., Kostick, S., \& Malnoy, M. 2020. Status of fire blight resistance breeding in Malus. $J$ Plant Path https://doi.org/10.1007/s42161-020-00581-8.

Peters, G. (2018). Userfriendlyscience: Quantitative analysis made accessible. R package version 0.7.2.

Puławska, J., \& Sobiczewski, P. (2012). Phenotypic and genetic diversity of Erwinia amylovora the causal agent of fire blight. Trees, 26, 3-12.

R Core Team (2019). R: A language and environment for statistical computing. R Foundation for Statistical Computing . URL https://www.R-project.org/

Richter, K., \& Fischer, C. (2002). Stability of fire blight resistance in apple. Acta Horticulturae, 590, 381-384.

E. Silfverberg-Dilworth, C. L. Matasci, W. E. Van de Weg, M. P. W. Van Kaauwen, M. Walser, L. P. Kodde, V. Soglio, L. Gianfranceschi, C. E. Durel, F. Costa, T. Yamamoto, B. Koller, C. Gessler, A. Patocchi. (2006) Microsatellite markers spanning the apple (Malus $\mathrm{x}$ domestica Borkh.) genome Tree Genetics \& Genomes (2), 202-224.

Sillerova, J., Korba, J., Paprstein, F., \& Sedlak, J. (2014). Testing of susceptibility level of Czech apple cultivars to fire blight (Erwinia amylovora) in field conditions. Acta Horticulturae, 1056, 267-270.

Sobiczewski, P., Żurawicz, E., Berczyński, S., \& Lewandowski, M. (2004). Terminal shoot susceptibility of new polish apple cultigens to fire blight (Erwinia amylovora). Folia Horticult, 16(2), 149-157.

Sobiczewski, P., Żurawicz, E., Berczyński, S., \& Lewandowski, M. (2006). Fire blight susceptibility of new apple cultivars and clones from Poland. Acta Horticulturae, 704, 551-556.

Sobiczewski, P., Peil, A., Mikiciński, A., Richter, K., Lewandowski, M., Żurawicz, E., \& Kellerhals, M. (2015). Susceptibility of apple genotypes from European genetic resources to fire blight (Erwinia amylovora). Eur J Plant Path141, 51-62.

Sobiczewski, P., Iakimova, E. T., Mikiciński, A., WegrzynowiczLesiak, E., \& Dyki, B. (2017). Necrotrophic behaviour of Erwinia amylovora in apple and tobacco leaf tissues. Plant Pathology, 66, 842-855. 
Toth, M., Kasa, K., Gondor, M., Honty, K., \& Hevesi, M. (2006). First results of fire blight resistance screening in a Hungarian breeding programme. Acta Horticulturae, 704, 545-549.

van de Weg, E., Di Guardo, M., Jänsch, M., Socquet-Juglard, D., Costa, F., Baumgartner, I., Broggini, G. A. L., Kellerhals, M., Troggio, M., Laurens, F., Durel, C.-E., \& Patocchi, A. (2018). Epistatic fire blight resistance QTL alleles in apple cultivar 'Enterprice' and selection X-6398 discovered and characterized through pedigree-informed analysis. Mol Breeding, 38, 5.

van der Zwet, T., Orolaza-Halbrendt, N., \& Zeller, W. (2012). Fire blight. History, biology and management. The American Phytopathological society: APS Press.

Vanneste, J. L. (2000). What is fire blight? Who is Erwinia amylovora? How to control it? In J. L. Vanneste (Ed.), Fire blight: The disease and its causative agent, Erwinia amylovora (pp. 1-6). CABI Publishing. 